\title{
RISK FACTORS ASSOCIATED WITH THE PRESENTATION OF BRUCELLOSIS IN THE SPINE
}

\author{
FATORES DE RISCO ASSOCIADOS À APRESENTAÇÃO DE BRUCELOSE NA \\ COLUNA VERTEBRAL
}

\author{
FACTORES DE RIESGO ASOCIADOS A LA PRESENTACIÓN DE BRUCELOSIS \\ EN LA COLUMNA VERTEBRAL
}

Alberto Aceves Pérez ${ }^{1}$

\begin{abstract}
Objective: The aim of this study is to describe the risk factors associated with the presentation of brucellosis on the spine, and determine the strength of association between these factors. Methods: The medical records of patients with brucellosis on the spine were analyzed and a spreadsheet was created to compile the following data: age, sex, place of origin and residence, risk factors (exposure at work, consumption of unpasteurized products and comorbidities), clinical presentation (lumbar pain, anorexia, headache, myalgia, fatigue, paresthesia, dysesthesia, muscle weakness, weight loss, fever), affected spine level, presence of abscesses, disease duration (acute, subacute, chronic), laboratory studies (erythrocyte sedimentation rate, C-reactive protein, serology, blood culture, Rose Bengal test, histopathological reports), imaging studies (x-rays, MRI, bone gammagraphy), established treatment (medical and/or surgical), therapeutic failure and sequelae. Results: A total of 17 patients, 10 women (58.8\%) and seven men (41.2\%), were reviewed from January 2007 to January 2011. The group had a mean age of 57.8 years with a standard deviation of +13.91 and age range between $16-74$ years. Conclusions: There is no significant difference between the groups compared with respect to age and sex, however, improvement of the neurological deficit was observed in eight patients who underwent surgical procedure.
\end{abstract}

Keywords: Brucellosis; Spine; Therapeutics; Prognosis; Risk factors.

\section{RESUMO}

Objetivo: O objetivo deste estudo é descrever os fatores de risco associados à apresentação de brucelose na coluna vertebral e determinar a força da associação entre esses fatores. Métodos: O prontuários médicos dos pacientes com brucelose na coluna foram analisados e uma planilha foi criada para reunir os seguintes dados: idade, sexo, local de origem e residência, fatores de risco (exposição no trabalho, consumo de produtos não pasteurizados e comorbidades), quadro clínico (dor lombar, anorexia, cefaleia, mialgia, fadiga, parestesia, disestesia, fraqueza muscular, perda de peso, febre), nível da coluna afetado, presença de abscessos, duração da doença (aguda, subaguda, crônica), exames laboratoriais (velocidade de hemossedimentação, proteína C-reativa, sorologia, hemocultura, teste de Rosa Bengala, exames histopatológicos), exames de imagem (radiografia, ressonância magnética, gamagrafia óssea), tratamento estabelecido (médico e/ou cirúrgico), falha terapêutica e sequelas. Resultados: Dezessete pacientes, 10 mulheres (58,8\%) e sete homens (41,2\%), foram analisados entre janeiro de 2007 e janeiro de 2011. A idade média do grupo foi 57,8 anos com desvio padrão de +13,91 e variação de 16-74 anos. Conclusões: Não há diferença significativa entre os grupos comparados em relação à idade e ao sexo, mas foi observada melhora no déficit neurológico de oito pacientes que foram submetidos a procedimentos cirúrgicos.

Descritores: Brucelose; Coluna vertebral; Terapêutica; Prognóstico; Fatores de risco.

\section{RESUMEN}

Objetivo: El objetivo del presente estudio es describir los factores de riesgo asociados a la presentación de brucelosis en la columna vertebral, y determinar la fuerza de asociación que existe entre dichos factores. Métodos: Se analizaron a través de los expedientes, las historias clínicas de pacientes con brucelosis en columna vertebral, y se elaboró una hoja de captura obteniéndose los datos registrados en el expediente clínico: edad, sexo, lugar de origen y residencia, factores de riesgo (exposición laboral, consumo de productos no pasteurizados, enfermedades concomitantes), cuadro clínico (dolor lumbar, anorexia, cefalea, mialgias, fatiga, parestesias, disestesias, debilidad muscular, pérdida de peso, fiebre) nivel afectado en columna, presencia de abscesos, duración de la enfermedad (aguda, subaguda, crónica), estudios de laboratorio (Velocidad de sedimentación globular, Proteína C reactiva, pruebas serológicas, cultivos, Rosa de Bengala, reportes histopatológicos), estudios de gabinete (radiografías, resonancia magnética, gammagrama óseo), tratamiento establecido (médico y/o quirúrgico), falla terapéutica y secuelas. Resultados: Se revisaron un total de 17 pacientes de 10 (58,8\%) mujeres, siete (41,2\%) hombres de enero de 2007 a enero de 2011, el grupo tuvo un promedio de edad de 57,8 años con una desviación estándar \pm 13,91 y un rango de 16 a 74 años. Conclusiones: No existe diferencia significativa entre los grupos comparados con respecto a edad y sexo, sin embargo, se observó mejoría del déficit neurológico en ocho pacientes a los que se les realizó un procedimiento quirúrgico.

Descriptores: Brucelosis; Columna vertebral; Terapéutica; Pronóstico; Factores de riesgo.

1. Orthopedics Service of the Centro Médico Nacional de Occidente, IMSS in Guadalajara, Jalisco, Mexico.

Study conducted at the Unidad Médica de Alta Especialidad del Centro Médico Nacional de Occidente "Lic. Ignacio García Téllez", in Guadalajara, Jalisco, Mexico. Correspondence: Av. Circunvalación Jorge Álvarez del Castillo, 1.558 - Colonia Chapultepec Country. 44610 - Guadalaraja, Mexico. alberthoap@ hotmail.com 


\section{INTRODUCTION}

Brucellosis is a worldwide disease characterized by a systemic infection caused by facultative intracellular bacteria of the genus Brucella, ${ }^{1,2}$ transmitted either by direct contact with secretions of infected animals, of through consumption of unpasteurized dairy products. . $^{3,4}$

Brucella melitensis is the strain considered to be responsible for infection in humans ${ }^{5,6}$ and there are various complications, but the musculoskeletal system is the most commonly affected, with complications reported in up to $40 \%$ of cases. The most affected location is the spine, with an incidence of between $2 \%$ and $60 \%{ }^{4-6}$

The vertebral levels most commonly involved are L4-L5, L5-S1. ${ }^{1}$ The symptoms are nonspecific, the most commonly reported being low back pain followed by fever, myalgia, and fatigue. ${ }^{3,7}$

Clinically, it is presented as rigidity of a vertebral segment caused by contraction of the paravertebral muscles, and in rare cases, as compression of the spinal cord or the nerve roots. ${ }^{4}$

Infection begins in the upper platform, due to its high vascularity, although it can affect the complete vertebral body and spread to the contiguous disc and subadjacent vertebra as a secondary process. Complications such as granulomatous epidural and paravertebral abscesses may be present, especially when there is cervical or thoracic spondylitis. ${ }^{8,9}$ (Figure 1)

A definitive diagnosis is established through clinical correlation, isolation of the Brucella species in blood and bone marrow cultures, and the presence of the microorganism in the histopathological study. ${ }^{3}$

It is suggested that the diagnosis be established by the presence of at least two of the following criteria:

1) Clinical profile compatible with brucellosis;

2) Positive serology for Brucella through the detection of specific antibodies with titers $\geq 1 / 160$ or through an increase of at least 4 or more of the antibody titers in blood samples taken 2-3 weeks after the first exam;

3) Radiological findings that suggest spinal infection;

4) Isolation of the bacteria in blood or tissue simple;

5) Histological findings that include chronic nonspecific inflammation and non-caseating tissue. .,10 $^{6}$

Radiographically, local or diffuse involvement may be observed. However, the changes are not visible until three months following the start of the infection. ${ }^{1,5,9}$ If it does not progress, a focal area of destruction in the discovertebral joint is observed. If it continues, the disc, the vertebral body, the paraspinal tissue, the adjacent vertebra, and the epidural space may be involved. ${ }^{6,11}$ The Pons' sign, which is characterized by focal erosions of the upper or lower vertebral body, is the characteristic radiological finding in brucellosis., ${ }^{1,4}$
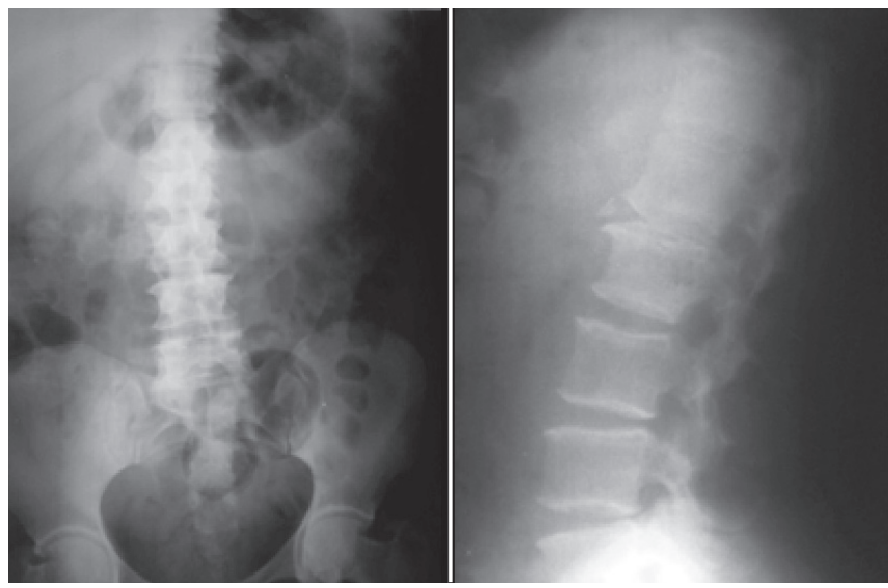

Figure 1. Radiographic appearance of brucellosis in the lumbar spine of a 54-year-old female patient, showing stenosis of the intervertebral space, destruction of the upper platform, and erosion of the upper angle of the vertebra (Pons' sign).
MRI provides an excellent definition of the paravertebral or epidural extension, and reveals the intervertebral disc and the adjacent vertebral bodies as hypointense in $\mathrm{T} 1$ and hyperintense in T2. ${ }^{6,9}$ (Figure 2)

Gammagraphy enables early detection of all the sites affected by the disease, with sensitivity of $69-91 \%$. $^{1,4}$

The disease has a predilection for the low lumbar spine. The architecture of the vertebral body is preserved, with diffuse vertebral osteomyelitis, compromise of the disc, poorly encased spinal tissue, and the absence of hump deformity that distinguishes it from other granulomatous diseases. ${ }^{6,8}$

Laboratory tests, such as blood cultures, are diagnostic, but they are rarely positive. Serological tests are very sensitive (98\%). Tissue cultures are diagnostic, but with a high rate of false negatives. ${ }^{11}$

Once the diagnosis is made, treatment is focused on eradicating the disease, maintaining the stability of the spine, and preventing or minimizing the neurological impacts. ${ }^{12}$

While there is no standard treatment for infection, the administration of antibiotics is the basis for treatment and surgery is indicated for epidural abscesses that cause neurological symptoms or comprise sagittal balance. ${ }^{1,6}$

The World Health Organization recommends first line therapy of $500 \mathrm{mg}$ of tetracycline every six hours, or $100 \mathrm{mg}$ of doxycycline every twelve hours, taken orally for eight weeks, with an aminoglycoside (one gram daily of streptomycin, administered intramuscularly) for two to three weeks. ${ }^{1,13}$ Failure of the therapy, as well as an increased risk of adverse reactions, is very common with the combination of doxycycline and streptomycin

Therefore, the main alternative is a combination of rifampicin with doxycycline. ${ }^{1,5}$ Following a twelve-week regimen, no relapses were reported during a one-year follow-up. ${ }^{5}$ In the case of paravertebral or epidural abscesses, the treatment can be extended up to twelve months. ${ }^{14}$

The role of the surgeon in patients with neurological symptoms is controversial. ${ }^{15}$ The goal of surgical intervention is to obtain tissue suitable for histological and bacteriological diagnosis, as well as to promote healing by stimulating the granulated tissue of the subchondral region of the vertebral body to invade and heal the avascular intervertebral disk. ${ }^{8}$

Surgery should be considered the last resort, as patients respond well to treatment with antibiotics. ${ }^{1}$ Surgery is reserved for patients with neurological deficit caused by bone deformities and purulent epidural abscesses, and the possibility of irreversible neurological damage is considered to be an absolute indication for surgery. ${ }^{8}$ (Figure 3)

A study conducted in patients with septic spondylitis (including brucellosis) reported neurological improvements, pain relief, and

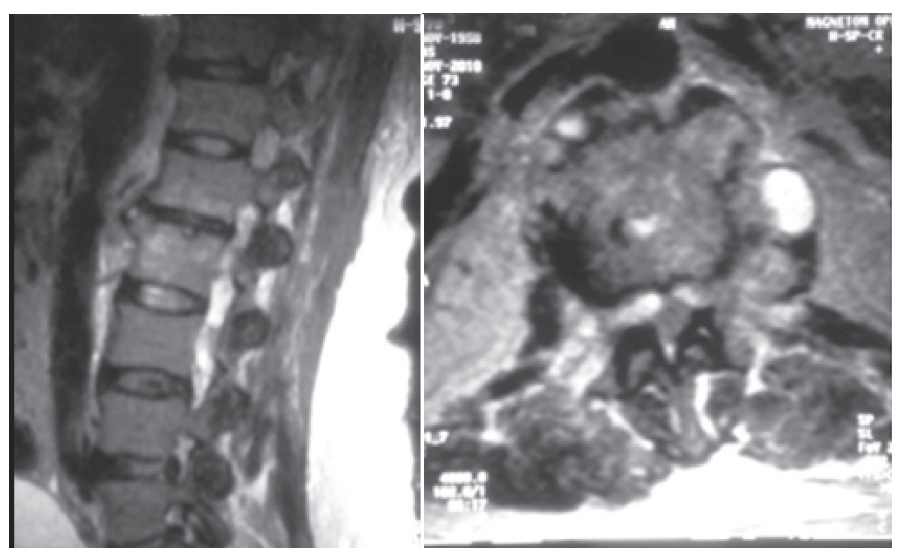

Figure 2. MRI of the lumbar spine in T2 sagittal view showing a hyperintense lesion affecting the vertebral body of T12 and L1 with the presence of a prevertebral abscess, as well as hypointensity in the intervertebral space of T12-L1. In the axial view, a lesion of the vertebral body and an image showing an irregular hypointense mass are observed. 


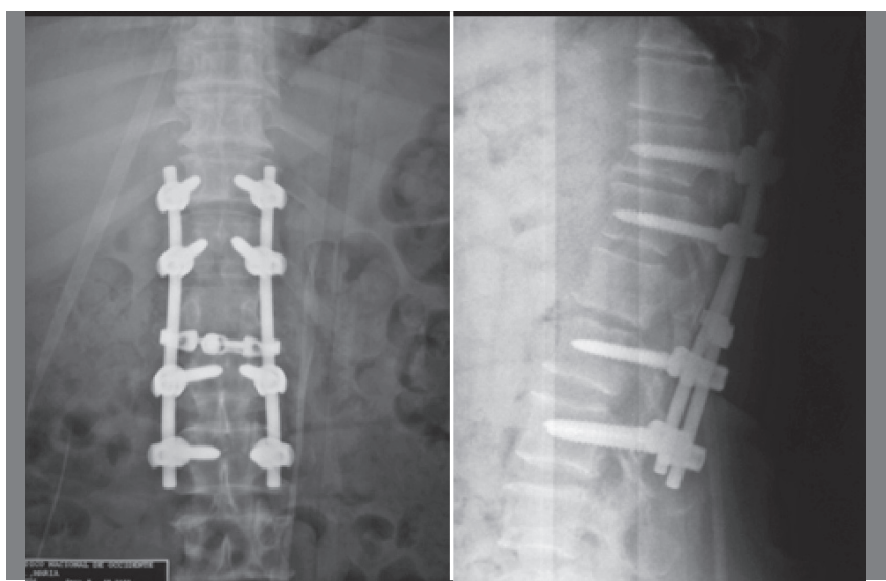

Figure 3. Postoperative radiographic control in which the posterior transpedicular instrumentation system can be seen, showing an improvement of both the T12-L1 intervertebral space and sagittal balance.

preservation of the sagittal balance of the spine when posterior instrumentation, posterior fusion, and placement of a titanium cage with an autologous graft by anterior approach at the site of the infection were performed during the same surgery. ${ }^{8,16}$

\section{MATERIAL AND METHODS}

A study of cases and controls was conducted in patients diagnosed and treated conservatively and surgically in the Unidad Médica de Alta Especialidad [High Specialization Medical Unit] of the Centro Médico Nacional de Occidente "Lic. Ignacio García Téllez", in Guadalajara, Jalisco, from January 2007 to January 2011.

The clinical histories of patients with brucellosis of the spine were analyzed, and a form was filled out with age, sex, birthplace and address, risk factors (exposure at work, consumption of non-pasteurized products, and concomitant illnesses), clinical profile (low back pain, anorexia, headache, myalgia, fatigue, paresthesia, dysesthesia, muscle weakness, weight loss, fever), the spinal level affected, presence of paravertebral abscesses, duration of the illness (acute, subacute, chronic), laboratory exams (ESR, CRP, serology tests, cultures, Rose Bengal, histopathological reports), imaging studies (radiographs, magnetic resonance, bone gammagraphs), established treatments (medical and surgical), therapeutic failure, and sequelae.

\section{Statistical methods}

The information was encoded, tabulated, and analyzed using computer programs (Epi Info Ver. 3.5.1 and SPSS Ver. 10.0) which calculate absolute and relative frequencies as well as measurements of central and dispersion tendency and association (OR) using Fisher's exact test, considering those with $p<0.05$ to be significant.

\section{RESULTS}

During the period January 2007 to January 2011, 17 patients were diagnosed with brucellosis in the spine, 10 of whom (58.8\%) were female and 7 of whom (41.2\%) were male, ranging from 16 to 74 years of age, with an average age of 57.8 (SD of 13.91). Seven $(41.2 \%)$ were housewives, one $(11.8 \%)$ was a peasant farmer, one (11.8\%) was a veterinarian, and the other seven (41.2\%) fell into the "other" category. Included among the risk factors reported were 13 (76.5\%) patients who had consumed unpasteurized products, one (5.9\%) who had had contact with infected animals, and 3 (17.6\%) for whom no risk was reported.

Clinically, 11 of the patients (64.7\%) had fevers, 2 (11.8\%) referred to having suffered periods of headaches, $3(17.6 \%)$ with myalgia and fatigue, 4 (23.5\%) had anorexia, and 6 (35.3\%) reported weight loss. Neurological examination revealed 2 patients (11.8\%) with Frankel grade A spinal cord function, 1 patient (5.9\%) with grade B, 1 patient (5.9\%) with grade C, 7 patients $(41.2 \%)$ with grade D, and 6 (35.3\%) with grade E. Four patients $(23.5 \%)$ had osteoarticular manifestations in the acute phase of the disease, $11(64.7 \%)$ in the subacute phase, and 2 (11.8\%) in the chronic phase. The levels affected were L4-L5 in 4 patients (23.5\%), level L1-L2 in 4 patients (23.52\%), level L5-S1 in 2 patients (16.7\%), level T6-T7 in 1 patient (5.8\%), level L2-L3 in 1 patient (5.8\%), level T6-T10 in 1 patient (5.8\%), level L1-L3 in 2 patients $(11.7 \%)$, and level L4-S1 in 2 patients (11.7\%). From a radiographical perspective, a discovertebral joint was reported in 3 patients (17.6\%), a focal area of destruction in 3 patients (17.6\%), involvement of the vertebral disc in 7 patients (41.2\%), involvement of the vertebral body in 8 patients $(47.1 \%), 3$ patients with involvement of the paraspinal tissue $(17.6 \%), 5$ patients $(29.4 \%)$ with involvement of the epidural space, and 2 patients (11.8\%) with the presence of bone spurs.

The gammagraphy showed impact to other locations (costal arches and sacrum) in 3 patients (17.6\%).

In the magnetic resonance imaging, hypointensity of the disc and body of T1 and hyperintensity of the disc and body of T2 were observed in all 17 patients (100\%), and abscesses were observed in 8 patients $(47.1 \%)$.

The results of the ESR, CRP, and Rose Bengal laboratory tests were positive in all 17 patients (100\%), serology was positive for Brucella in 3 patients (17.6\%), Hudlesson was positive in 15 patients (88.2\%), and 2-mercaptoethanol was positive in 6 patients $(35.5 \%)$.

The medical treatment administered to 15 patients (88.2\%) was based on doxycycline, rifampicin, and ciprofloxacin, for a period of 24 weeks in 8 patients (47.1\%), 12 weeks in 4 patients $(23.5 \%), 8$ weeks in 3 patients (17.6\%), and 12 months in 2 patients (11.8\%). Therapeutic failure was reported in 3 of the patients $(17.6 \%)$ who had received doxycycline and rifampicin for 12 weeks.

Surgical treatment was performed in 11 patients, with drainage of abscesses in 2 patients (11.6\%) and posterior instrumentation and fusion in 8 patients (47.0\%). Fourteen patients (82.4\%) were reported to be without sequelae, 2 patients (11.8\%) with moderate sequelae, and 1 patient (5.9\%) with severe neurological damage.

Inferential analysis was performed for comparisons between age, sex, Frankel grade, level affected, and type of treatment, and we observed that in patients aged over 60 years at Frankel levels $A-E$, the OR was $0.42(\mathrm{Cl} 95 \%$ of $0.03-4.84)$ and $p>0.05$, in patients older than 60 years of age who underwent surgical treatment the OR was $0.42(\mathrm{Cl} 95 \%$ of $0.03-4.84)$ and $\mathrm{p}>0.5$ compared to the control group. Similarly, in female patients who underwent surgery the OR was 0.17 ( $\mathrm{Cl} 95 \%$ of $0.01-2.62)$ and $\mathrm{p}>0.05$ compared to the control group. (Table 1)

Table 1. Distribution of Risk Factors.

\begin{tabular}{c|c|c|c|c|c|c|c}
\hline Variables & & $\%$ & & $\%$ & OR & Cl 95\% & P \\
\hline Age & $>60$ & & $<59$ & & & & \\
\hline Surgical Tx & 5 & 29.41 & 6 & 35.29 & 0.42 & $0.03-4.84$ & $>0.05$ \\
\hline Conserv. Tx & 4 & 23.52 & 2 & 11.76 & 1 & & \\
\hline Sex & Female & & Male & & & & \\
\hline Surgical Tx & 5 & 29.41 & 6 & 35.29 & 0.17 & $0.01-2.62$ & $>0.05$ \\
\hline Conserv. Tx & 5 & 29.41 & 1 & 5.88 & 1 & & \\
\hline Age & $>60$ & & $<59$ & & & & \\
\hline Frankel A-D & 5 & 29.41 & 6 & 35.29 & 0.42 & $0.03-4.84$ & $>0.05$ \\
\hline Frankel E & 4 & 23.52 & 2 & 11.76 & 1 & & \\
\hline Sex & Female & & Male & & & & \\
\hline Frankel A-C & 2 & 11.76 & 2 & 11.76 & 0.63 & $0.04-9.59$ & $>0.05$ \\
\hline Frankel D-E & 8 & 47.05 & 5 & 29.41 & 1 & & \\
\hline Treatment & Surgical & & Conservative & & & & \\
\hline Frankel A-C & 4 & 23.52 & 0 & & & & $>0.05$ \\
\hline Frankel D-E & 7 & 41.17 & 6 & 35.29 & & & \\
\hline
\end{tabular}




\section{DISCUSSION}

Brucellosis is an infectious disease, the most common complication of which is impacts on the musculoskeletal system, usually the spine. ${ }^{1,5}$ To date there are no studies that define the risk factors and the level of the association of said factors with the outcome of surgical treatment is performed.

For this research, we studied 17 patients diagnosed and treated at the Centro Médico Nacional de Occidente over a four-year period, and found that they all presented low back pain as the predominant symptom, and while this was the most common symptom, ${ }^{8}$ or rather, the only symptom to manifest itself, as the rest of the clinical profile was nonspecific.

Eleven of the patients had neurological changes in the lower limbs which were evaluated using the Frankel scale.

The lumbar spine was the most affected location, particularly at level L4-L5. However, one patient had injuries at thoracic levels T6 through T11. Imaging study findings reported involvement of the vertebral body, disc, and adjacent vertebra, with hypointensity of the disc and body of $\mathrm{T} 1$ and hyperintensity of the disc and body in T2 reported in all patients. Eight patients had paraspinal abscesses. MRI was the most useful technique for detecting the disease. ${ }^{17}$ Results from ESR, CRP, and the Rose Bengal laboratory tests were positive for all patients and in 3 patients, bone gammagraphy revealed impact to the sacrum and ribs.

Treatment based on antibiotic therapy with doxycycline/rifampicin was instituted for all patients, six of whom only were only given medication as they did not present neurological deficit. The other 11 patients presented neurological impairment in the pelvic limbs, which is an absolute indication for surgery, and underwent posterior instrumentation and in cases with abscesses, drainage was performed. Clinical improvement of the neurological state was observed in 8 patients.
A 12-week regimen of the antibiotic of choice (doxycycline/streptomycin) followed. ${ }^{5}$

The average duration of antibiotic treatment was 24 weeks, with treatment failure occurring in only 3 patients who presented signs and symptoms of illness in spite of the medical treatment, which we consider to be in line with other studies ${ }^{8}$ in which antibiotics were administered over 24 weeks.

We observed that there was no significant statistical difference in terms of sex or age, however, 8 of the 11 patients with neurological changes underwent decompression surgery, which clinically improved their neurological status.

Early and accurate diagnosis of brucellosis is important in order to avoid complications. The prognosis of the disease is good, and mortality is rare, with no deaths reported up until the end of this study.

If the disease is detected early and managed properly, the prognosis is good, mortality is low, and severe sequelae are rare.

Sample size was a limitation of this study, but because the sample was taken from a hospital specialized in a relatively rare pathology, we were able to observe its clinical evolution and the possible diagnoses, treatments, and prognoses.

\section{CONCLUSIONS}

These data allowed us to obtain real, accurate information that enables Clinical Guides for the management of patients with brucellosis of the Spine to be started or updated in the future.

All authors declare no potential conflict of interest concerning this article.

\section{REFERENCES}

1. Alp E, Doganay M. Current therapeutic strategy in spinal brucellosis. Int J Infect Dis. 2008;12(6):573-7.

2. Görgülü A, Albayrak BS, Görgülü E, Tural O, Karaaslan T, Oyar O, Yilmaz M. Spinal epidura abscess due to Brucella. Surg Neurol. 2006;66(2):141-6;

3. Hong Jae L. Jin Woo H. Jong Won L. Brucellar spondylitits: a case report. J Korean Neurosurg Soc. 2008:44:277-9.

4. Chelli Bouaziz M, Ladeb MF, Chakroun M, Chaabane S. Spinal brucellosis: a review. Skeletal Radiol. 2008;37(9):785-90.

5. Alp E, Koc RK, Durak AC, Yildiz O, Aygen B, Sumerkan B, et al. Doxycycline plus streptomycin versus ciprofloxacin plus rifampicin in spinal brucellosis [ISRCTN31053647]. BMC Infect Dis. 2006;6:72.

6. Turgut M, Turgut AT, Koşar U. Spinal brucellosis: Turkish experience based on 452 cases published during the last century. Acta Neurochir (Wien). 2006;148(10):1033-44.

7. Nas K, Gür A, Kemaloğlu MS, Geyik MF, Cevik R, Büke Y, et al. Management of spinal brucellosis and outcome of rehabilitation. Spinal Cord. 2001;39(4):223-7.

8. Katonis P,Tzermiadianos M, Gikas A, Papagelopoulos P, Hadjipavlou A. Surgical treatment of spinal brucellosis. Clin Orthop Relat Res. 2006;444:66-72.

9. Hizel K, Guzel O, Dizbay M, Karakus R, Senol E, Arman D, et al. Age and duration of disease as factors affecting clinical findings and sacroiliitis in brucellosis. Infection. 2007;35(6):434-7.

10. Kim DH, Cho YD. A case of spondylodiscitis with spinal epidural abscess due to Brucella. J Korean Neurosurg Soc. 2008;43(1):37-40.

11. Reitman CA, Watters WC 3rd. Spinal brucellosis: case report in the United States. Spine (Phila Pa 1976). 2002;27(9):E250-2

12. Swanson AN, Pappou IP, Cammisa FP, Girardi FP. Chronic infections of the spine: surgical indications and treatments. Clin Orthop Relat Res. 2006;444:100-6.

13. Tur BS, Suldur N, Ataman S, Ozturk EA, Bingol A, Atay MB. Brucellar spondylitis: a rare cause of spinal cord compression. Spinal Cord. 2004;42(5):321-4.

14. Ozden M, Demirdag K, Kalkan A, Ozdemir H, Yuce P. A case of brucella spondylodiscitis with extended, multiple-level involvement. South Med J. 2005;98(2):229-31.

15. Turunc T, DemirogluYZ, Uncu H, Colakoglu S, Arslan H. A comparative analysis of tuberculous, brucellar and pyogenic spontaneous spondylodiscitis patients. J Infect. 2007;55(2):158-63.

16. Korovessis P, Petsinis G, Koureas G, lliopoulos P, Zacharatos S. One-stage combined surgery with mesh cages for treatment of septic spondylitis. Clin Orthop Relat Res. 2006:444:51-9.

17. Ozaksoy D, Yücesoy K, Yücesoy M, Kovanlikaya I, Yüce A, Naderi S. Brucellar spondylitis: MRI findings. Eur Spine J. 2001;10(6):529-33. 